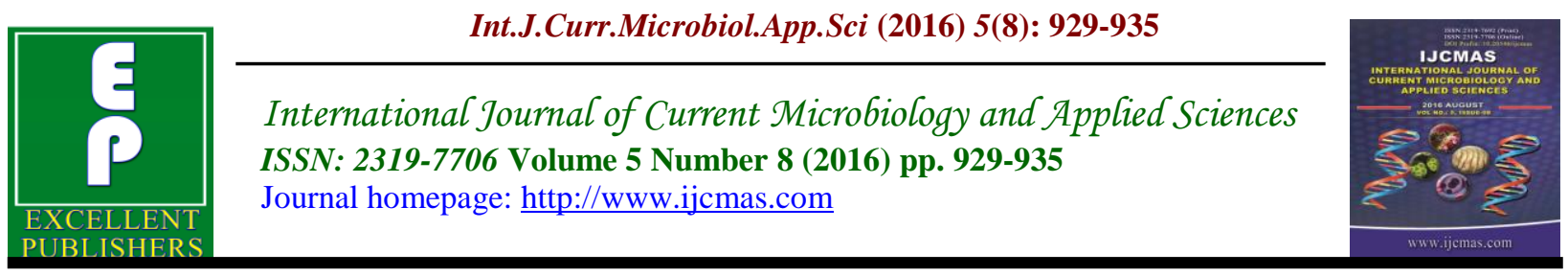

Original Research Article

http://dx.doi.org/10.20546/ijcmas.2016.508.104

\title{
Pathogenecity of Dental Caries; Isolation and Antimicrobial Efficacy by Herbal Plants
}

\author{
Padma Shri Mishra $^{1 *}$, Shrikant Kol ${ }^{1}$, Rashmi Arnold ${ }^{3}$ and R.M. Mishra ${ }^{2}$ \\ ${ }^{1}$ Research scholar, Center for Biotechnology Studies, A.P.S.University, Rewa (M.P.), India \\ ${ }^{2}$ H.O.D, Center for Biotechnology Studies, A.P.S.University, Rewa (M.P.), India \\ ${ }^{3}$ Professor Botany, Govt. Model Science Colleges, Rewa (M.P.), India \\ *Corresponding author
}

Keywords

Oral disease, mouth, saliva, pioneer, periodontitis dental caries.

\begin{tabular}{l}
\hline Article Info \\
\hline Accepted: \\
28 July 2016 \\
Available Online: \\
10 August 2016
\end{tabular}

\section{A B S T R A C T}

WHO's report on the Global Problem of Oral Diseases, that oral diseases such as dental caries (tooth decay), periodontitis (gum disease) and oral and pharyngeal cancers are global health problem in both the industrialized and the developing countries, especially among poorer communities. The mouth can be considered an ideal environment for the growth of microorganisms, since it is warm and moist and has a constant influx of nutrients through saliva and food intake. Lactobacilli are known to favour the dorsum of the tongue, while Streptococcus mutans requires a solid, non-shedding surface for colonization, as demonstrated by the rapid appearance of $S$. mutans in the mouth of toothless infants when obturators are inserted to fix cleft palates. This complex relationship even consists of bacteria whose presence is contingent on other "pioneer" bacterial species. It has even been demonstrated that certain oral microorganisms can cooperate in a mutuality manner for a common benefit, as when species collaborate by using different speciesspecific enzymes to break down complex host molecules that could not be metabolized by a single species. In this study we have tried to find out the herbal solution of dental caries by checking their antimicrobial activity.

\section{Introduction}

Oral health can be defined as being free from chronic mouth and facial pain, oral sores, periodontal (gum) disease, tooth decay, tooth loss and other diseases/disorders that affect the mouth and oral cavity. The mouth can be considered an ideal environment for the growth of microorganisms, because it is warm and moist and has a constant influx of nutrients through saliva and food intake. Oral infections are one of the most common diseases worldwide, leading to dental caries and periodontal disease (Petersen, 2005). A significant increase in the total caries experience and small increase in the number of carious lesions was found by about 17th century. Due to penetration of civilization to almost all areas of the world, dental caries has become a universal disease. The incidence of dental caries varies with geographic areas and dietary habits (Sivpathasudharam et al., 2009). In India, 
dental caries affect $60-65 \%$ of the general population. In addition; periodontal disease is estimated to occur in 50-90\% of the population in India, depending on age (Kaur, 2009). Dental caries is an infectious microbial disease that results in localized dissolution and destruction of the calcified tissues of the teeth or it is the localized destruction of susceptible dental hard tissues by acidic by-products from bacterial fermentation of dietary carbohydrates. The acid released through microbial action would cause local $\mathrm{pH}$ to fall below a critical value resulting in demineralization and cavitations of tooth (Loesche, 1986; Islam et al., 2007; Hamada et al., 1980; Kidd et al., 2004). Literature survey reveal several reports on herbal formulations against dental diseases viz., chewable tablets for anticariogenic activity against Streptococcus mutans (Saraya et al., 2008). The mouth can be considered an ideal environment for the growth of microorganisms, since it is warm and moist and has a constant influx of nutrients through saliva and food intake. In fact, it has been calculated that there are as many as $4 \times 10^{10}$ organisms in each gram of plaque removed from the teeth (Gibbons and Banghart, 1967). In fact, when cultures simulating a community of oral bacteria were pulsed with glucose to produce a constant $\mathrm{pH}$ lower than 5, the acidophilic species Lactobacillus casei, Veilonella dispar, and especially Streptococcus mutans were able to dominate niches previously occupied by other, avirulent species, and became irreversibly over-represented in the population (Marsh, 1992). Dental caries is a multifactoral infectious disease in which the active agent or agents are members of the indigenous oral flora (fig.1).

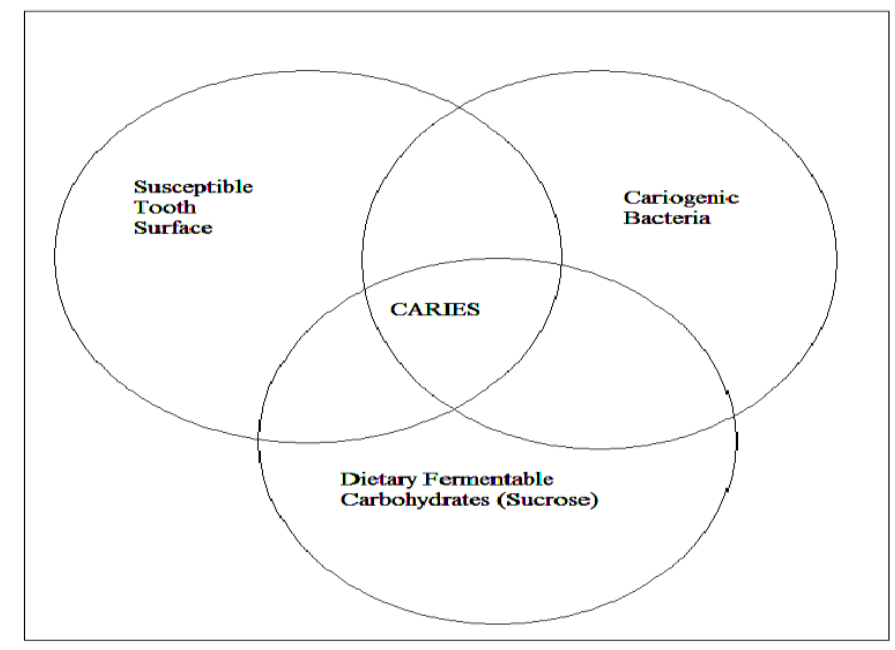

\section{Methodology}

\section{Sample collection}

For the collection of samples the local dental hospitals and private dental clinic has been visited properly and by concerning of patients, by the help and permission of dentist samples were collected. Allthe sample were collected from mouth by swabbing across the gingival and subgingival region as well as from the roof and floor of the bucal cavity. The samples were collected from 10 persons and were inoculated in Nutrient broth (HiMedia, India) and viable cells were enumerated.

\section{Enumeration of Viable Cell Count}

After the collection of samples, the overnight broth culture was serially diluted with autoclaved distilled water upto $10^{-0}$ to 
$10^{-10}$ dilution and 50-100 $\mu$ l of each dilution was spread on to Nutrient agar (HiMedia) plates and incubated overnight at $37^{\circ} \mathrm{C}$. After 18-20 hours incubation the number of viable colonies were counted using total viable plate count method (Lansing et al., 2005).

C.F.U/mL original sample $=$ Number of colonies /plate $x(1 / \mathrm{mL}$ aliquot plated $) \times$ dilution factor

\section{Isolation of Microbe}

For the isolation of microbes the nutrient agar plates were prepared and microbes were inoculated into them. After 30 hours of incubation at $30^{\circ} \mathrm{C}$, these microbes were streaked and isolated the individual species from the agar plates. These microbes were freshly prepared and stored in nutrient broth. We have isolated three strains for our study.i.e. A1,B1,C1. respectively.

\section{Methods of Extraction of Plant Material}

The methods of extraction are the process, where the desired constituents of a plant samples are extracted using selected solvent. The preliminary step involved in extraction is cell rupturing. Once the cells are ruptured extraction is performed using appropriate.

\section{Plant tissue homogenization}

This is widely used method for extraction.
Dried or wet fresh plants parts of the plants are grinded in a blender to fine particles. This is put in a certain quantity of solvent and shaken vigorously for 5-10 minutes or left for 24 hrs. After which the extract is filtered. The filtrate is dried under reduced pressure and then re-dissolved in the solvent (Raamann, 2006).

\section{Soxhlet Extraction}

This method is convenient and widely used for extraction because of its continuous process, less time and solvent consumption compared to maceration and percolation. However, this method cannot be used for thermo labile compounds as prolonged heating may lead to degradation of compounds.

In this method, plant material is dried and powdered. The powdered plant is placed in Soxhlet apparatus which is on the top, a collecting flask beneath a reflux condenser. A suitable solvent is added to flask and the set up is heated under reflux. The steam of solvent dissolves the ingredients of plant and brings back to a flask. Several cycles are carried out. The solvent is evaporated by using rotary evaporator or at room temperature. Dried extract is then kept in freeze (Ncube et al., 2006; Handa et al., 2008; Tiwari et al., 2011).

Plants used

\begin{tabular}{|l|l|l|l|l|}
\hline S. no. & Plants & Family & Common name & Parts used \\
\hline 1 & Curcuma longa & Zingiberaceae & Turmeric, Haldii & rhizome \\
\hline 2 & Fenugreek & Fabaceae & Meethi & seed \\
\hline 3 & Allium cepa & Amaryllidaceae & Onion & bulb \\
\hline 4 & Allium sativum & Amaryllidaceae & Garlic & bulb \\
\hline
\end{tabular}


Solvents Used

\begin{tabular}{|l|l|l|l|l|l|l|}
\hline $\begin{array}{l}\text { S. } \\
\text { no. }\end{array}$ & Solvent used & $\begin{array}{l}\text { Chemical } \\
\text { formula }\end{array}$ & Solubility & Molar mass & $\begin{array}{l}\text { Melting } \\
\text { point }\end{array}$ & $\begin{array}{l}\text { Boiling } \\
\text { point }\end{array}$ \\
\hline 1 & Ethanol & $\mathrm{C}_{2} \mathrm{H}_{6} \mathrm{O}$ & Water & $46.07 \mathrm{~g} / \mathrm{mol}$ & $-114{ }^{\circ} \mathrm{C}$ & $78.37{ }^{\circ} \mathrm{C}$ \\
\hline 2 & Methanol & $\mathrm{CH}_{3} \mathrm{OH}$ & Water & $32.04 \mathrm{~g} / \mathrm{mol}$ & $-97.6{ }^{\circ} \mathrm{C}$ & $64.7{ }^{\circ} \mathrm{C}$ \\
\hline 3 & Ethyl acetate & $\mathrm{C}_{4} \mathrm{H}_{8} \mathrm{O}_{2}$ & $\begin{array}{l}\text { Ethanol, } \\
\text { Acetone }\end{array}$ & $88.11 \mathrm{~g} / \mathrm{mol}$ & $-83.6^{\circ} \mathrm{C}$ & $77.1^{\circ} \mathrm{C}$ \\
\hline 4 & Chloroform & $\mathrm{CHCl}_{3}$ & Benzene & $119.37 \mathrm{~g} / \mathrm{mol}$ & $-63.5^{\circ} \mathrm{C}$ & $61.15^{\circ} \mathrm{C}$ \\
\hline
\end{tabular}

\section{Antimicrobial Activity}

Antibacterial activity of all extracts will be tested by agar well diffusion method. The culture plates will be prepared by pouring 30 ml Nutrient Agar Medium into sterile petri plates. Then swab test bacteria then swab over the agar media using sterile cotton swabs to get uniform distribution of the bacterial cultures. Make $6 \mathrm{~mm}$ diameter wells using sterile cork borer. Then fill the wells with the sample extracts by 30-50ul. Then incubate the anti-bacterial assay plates at $37^{\circ} \mathrm{C}$ for 24 hours. The diameter of the zone of inhibition around each well will be taken as a measure of antibacterial activity (Cavallito et al., 1994; Deresse, 2010; Prados-Rosales et al., 2003; Onyeagba et al., 2006).

\section{Results and Discussion}

All the samples were collected and grown on nutrient agar medium plates and observations were made to the next day. The isolated microbes were used for the antimicrobial test.

\section{Enumeration of Total Viable Cell Count}

Total viable count was determined from selected plates having 30 to 300 colonies (Table1).

Total viable count was calculated from the formula

$T H B=$ No. of colonies $\times$ Dilution factor $/$ Inoculums size CFU/ml

\section{Extraction of plant material}

For the extraction of solvents they were run into the apparatus for the 4 hours, and the extract were measured in $\mathrm{mg}$;

\section{Antimicrobial activity}

The antimicrobial activities of all the isolated strains (zone of inhibition) were measured in $\mathrm{mm}$.

\begin{tabular}{|l|l|l|l|l|}
\hline Plants used & Ethanol & Methanol & Ethyl acetate & Chloroform \\
\hline Curcuma longa & 0.41 & 0.33 & 0.45 & 0.22 \\
\hline fenugreek & 0.35 & 0.66 & 0.11 & 0.41 \\
\hline Allium cepa & 0.23 & 0.21 & 0.10 & 1.10 \\
\hline Allium sativum & 0.33 & 0.52 & 0.36 & 0.85 \\
\hline
\end{tabular}


Antimicrobial activity of Curcuma longa in the presence of strain isolated (A1, B1, and C1)

\begin{tabular}{|l|l|l|l|l|l|}
\hline Plant /Strain & DMSO & Ethanol & Methanol & Ethyl acetate & Chloroform \\
\hline Curcuma longa(A1) & 0.3 & 0.5 & 0.6 & 0.6 & 0.6 \\
\hline Curcuma longa(B1) & 0.0 & 0.2 & 1.6 & 0.7 & 0.3 \\
\hline Curcuma longa(C1) & 0.5 & 0.3 & 0.0 & 0.6 & 0.4 \\
\hline
\end{tabular}

Antimicrobial activity of fenugreek

\begin{tabular}{|l|l|l|l|l|l|}
\hline Plant /Strain & DMSO & Ethanol & Methanol & Ethyl acetate & Chloroform \\
\hline Fenugreek(A1) & 0.00 & 0.5 & 0.00 & 0.6 & 0.5 \\
\hline Fenugreek(B1) & 0.3 & 0.2 & 2.2 & 0.0 & 0.0 \\
\hline Fenugreek(C1) & 0.0 & 0.6 & 0.8 & 1.3 & 2.0 \\
\hline
\end{tabular}

Antimicrobial activity of Allium cepa

\begin{tabular}{|l|l|l|l|l|l|}
\hline Plant /Strain & DMSO & Ethanol & Methanol & Ethyl acetate & Chloroform \\
\hline Allium cepa(A1) & 0.00 & 1.3 & 0.9 & 1.9 & 0.5 \\
\hline Allium cepa(B1) & 0.3 & 2.0 & 0.9 & 0.5 & 0.0 \\
\hline Allium cepa(C1) & 0.6 & 1.2 & 1.6 & 0.9 & 1.0 \\
\hline
\end{tabular}

Antimicrobial activity of Allium sativum

\begin{tabular}{|l|l|l|l|l|l|}
\hline Plant & DMSO & Ethanol & Methanol & Ethyl acetate & Chloroform \\
\hline Allium sativum(A1) & 0.3 & 0.8 & 1.6 & 2.6 & 1.6 \\
\hline Allium sativum(B1) & 0.6 & 1.3 & 1.6 & 1.0 & 2.0 \\
\hline Allium sativum(C1) & 1.3 & 2.3 & 1.9 & 0.6 & 0.9 \\
\hline
\end{tabular}

Biochemical Characterization

\begin{tabular}{|l|l|l|l|}
\hline Sample No. & A1 & B1 & C1 \\
\hline Grams Staining & $+\mathrm{VE}$ & $-\mathrm{VE}$ & $+\mathrm{VE}$ \\
\hline Catalase Activity & $-\mathrm{VE}$ & $-\mathrm{VE}$ & $-\mathrm{VE}$ \\
\hline Oxidase Test & $-\mathrm{VE}$ & $-\mathrm{VE}$ & $-\mathrm{VE}$ \\
\hline Nitrate Test & $-\mathrm{VE}$ & $-\mathrm{VE}$ & $+\mathrm{VE}$ \\
\hline Indole Test & $\mathrm{VE}$ & $+\mathrm{VE}$ & $+\mathrm{VE}$ \\
\hline Glucose Acidification & $+\mathrm{VE}$ & $+\mathrm{VE}$ & $-\mathrm{VE}$ \\
\hline$\beta$-Galactosidase & $+\mathrm{VE}$ & $+\mathrm{VE}$ & $+\mathrm{VE}$ \\
\hline Bile esculin test & $+\mathrm{VE}$ & $-\mathrm{VE}$ & $-\mathrm{VE}$ \\
\hline MR-VP Test & $+\mathrm{VE}$ & $+\mathrm{VE}$ & $+\mathrm{VE}$ \\
\hline
\end{tabular}


Table.1 Viable cell count

\begin{tabular}{|c|c|c|c|}
\hline S.no. & Number of bacterial colonies & Dilution factor & THB $(\mathbf{C F U} / \mathbf{m l})$ \\
\hline 1. & 300 & $10^{-0}$ & $3.0 \times 10^{5}$ \\
\hline 2. & 280 & $10-2$ & $2.8 \times 10^{5}$ \\
\hline 3. & 250 & $10-3$ & $2.5 \times 10^{5}$ \\
\hline 4. & 200 & $10-4$ & $2.0 \times 10^{5}$ \\
\hline 5. & 180 & $10-5$ & $1.8 \times 10^{5}$ \\
\hline 6. & 180 & $10-6$ & $1.8 \times 10^{5}$ \\
\hline 7. & 150 & $10-7$ & $1.5 \times 10^{5}$ \\
\hline 8. & 142 & $10-8$ & $1.42 \times 10^{5}$ \\
\hline 9. & 120 & $10-9$ & $1.2 \times 10^{5}$ \\
\hline 10. & 70 & $10-10$ & $0.7 \times 10^{5}$ \\
\hline
\end{tabular}

Dental caries is an infectious and communicable disease. Multiple factors, such as the interaction of bacteria, diet, and host response, all influence dental caries initiation and progression. Saliva plays an important role in optimal oral health. By testing the variety of herbal parts, after recognizing the effective parameter for its extraction, its purification is to be highly emphasized upon. Freeze drying of the product and then consequently determining its anti-oxidative and antimicrobial properties will be the main work. There by, optimization of the properties will be of relatively high importance. Since its usage in product development has been found out, various other product developments may be done. After the biochemical test results we may find species were showing similarity to the Veilonella dispar and especially Streptococcus mutans. During the whole experimental procedure of extraction of herbal oils, after checking their ability on pathogens isolated they were showing positive responses, and may be their oils should be used in future solution of dental problems.

\section{References}

Cavallito, C.J., Bailey, J.H. 1994. Allicin, the antibacterial principle of Allium sativum 1. Isolation, physical properties and antibacterial action $J$. Am. Chem. Soc., 66: 1950-1951.

Deresse, D. 2010. Antibacterial Effect of Garlic (Allium sativum) on Staphylococcu aureus: An in vitro Study. Asian. J. Med. Sci., 2: 62- 65.

Farbman, K.S., Barnett, E.D., Boldiro, G.R., Klein, J.O. 1993. Antibacterial activity of garlic and onions: a historic perspective. Paediat. Infect. Dis., 12: 613-614.

Gibbons and Banghart, 1967. S. mutans cells adhere to teeth and to each other via glucans synthesized by "dextran sucrases" (glucosyl transferases), with sucrose as the natural substrate.

Hamada, S., Slade, H.D. 1980. Biology, immunology and cariogenicity of Streptococcus mutans. Microbiol. Rev., 44(2), 331.

Handa, S.S., Khanuja, S.P.S., Longo, G., Rakesh, D.D. 2008. Extraction technologies for medicinal and aromatic plants. International centre for science and high technology, Trieste, 21-25.

Islam, B., Khan, S.N., Khan, A.U. 2007. Dental caries: from infection to prevention. Med. Sci. Monit., 13(11), RA196. 
Kaur, J. 2009. Dental education and oral health problems in India. Indian $J$. Dent. Edu., 2:167-171

Kidd, E., Fejerskov, O. 2004. What constitutes dental caries? Histopathology of carious enamel and dentin related to the action of cariogenic biofilms. J. Dent. Res., 83 (suppl 1), C35-C38.

Lansing, M., Prescott, L.M., Harley, J.P. and Klein, D.A. 2005. Microbiol., 6e McGrawHill.

Loesche, W.J. 1986. Role of Streptococcus mutans in human dental decay. Microbiol. Rev., 50(4), 353.

Marsh, P.D. 1992. Microbiological aspects of the chemical control of plaque and gingivitis. $J$. dental resistance.

Ncube, N.S., Afalayan, A.J., Okoh, A.I. 2008. Assessment techniques of antimicrobial properties of natural compounds of plant origin : Current methods and future trends. African J. Biotechnol., 7(12) : 1797-1806.

Onyeagba, R.A., Ugbogu, O.C., Okeke, C.U., Iroakasi, O. 2006. Studies on the antimicrobial effects of garlic (Allium sativum Linn), ginger (Zingiber officinale Roscoe) and lime (Citrus aurantifolia Linn). Afr. J. Biotechnol., 3: 552-554.

Petersen, P.E. 2005. The burden of oral disease: challenges to improving oral health in the 21 st century. Bull. W. $H$. $O .$, 83, 3-33.

Prados-Rosales, R.C., Luque-Garcia, jl, Luque de Castro, M.D. 2003. Rapid analytical method for the determination of $\mathrm{p} 4$ sticides residues in sunflower seeds based on focused microwave-assisted soxhlet extraction, prior to GC-MS-MS. J. Chromatog., A 993: 121-129.

Raamann, N. 2006. Phytochemical techniques. New Age Publications, New Delhi.

Saraya, S., Kanta, J., Sarisuta, N., Temsiririrkkul, R., Suvathi, Y., Samranri, K., Chumnumwat, S. 2008. Development of guava extract chewable tablets for anticariogenic activity against Streptococcus mutans. Mahidol Univ. J. Pharma. Sci., 35(14), 18-23.

Sivpathasudharam, B. and A.R. Raghu. 2009. Dental caries, Shafter's textbook of oral pathology 6 th edition, Elsevier publication, pp 409.

Tiwari Prashant, Bimlesh kumar, Mandeep Kaur, Gurupreet Kaur, Harleen Kaur. 2009. Phytochemical screening and extraction: Agricultural Sciences at University of Hohenheim. A review. Int. Pharma. Sci.,1(1): 98-106.

\section{How to cite this article:}

Padma Shri Mishra, Shrikant Kol, Rashmi Arnold and R.M. Mishra. 2016. Pathogenecity of Dental Caries; Isolation and Antimicrobial Efficacy by Herbal Plants. Int.J.Curr.Microbiol.App.Sci. 5(7): 929-935. doi: http://dx.doi.org/10.20546/ijcmas.2016.507.104 